\title{
Author Correction: Pre-existing immunity to SARS-CoV-2: the knowns and unknowns
}

\author{
Alessandro Sette and Shane Crotty (1)
}

Nature Reviews Immunology (2020) https://doi.org/10.1038/s41577-020-0389-z Published online 07 July 2020

In the originally published article, a typographical error was introduced during editing. In the statement "In a third study, from Germany, Braun et al. ${ }^{3}$ reported positive T cell responses against spike peptides in $34 \%$ of SARS-CoV-2 seronegative healthy donors (CD4 ${ }^{+}$and CD $8^{+} \mathrm{T}$ cells were not distinguished).", the underlined part was intended to refer to a different study and has now been deleted. A second statement was edited for clarity. "Thiel and colleagues ${ }^{3}$ reported that the T cell reactivity was highest against a pool of SARS-CoV-2 spike peptides that had higher homology to CCCs, but the difference was not significant." has been changed to "Thiel and colleagues ${ }^{3}$ reported that the T cell reactivity was highest against a pool of SARS-CoV-2 spike peptides that had homology to CCCs."

https://doi.org/10.1038/s41577-020-00430-w I Published online 17 August 2020

๑) Springer Nature Limited 2020

\section{Author Correction: A few good peptides: MHC class I-based cancer immunosurveillance and immunoevasion}

\section{Devin Dersh, Jaroslav Hollý and Jonathan W. Yewdell(B)}

Nature Reviews Immunology (2020) https://doi.org/10.1038/s41577-020-0390-6 Published online 20 August 2020

The reference highlight that should accompany reference 121 (Patel et al.) was placed under reference 120 (Manguso et al.) in the article originally published online. This error has been corrected in the HTML and PDF versions of the article.

https://doi.org/10.1038/s41577-020-00445-3 I Published online 1 September 2020

This is a U.S. government work and not under copyright protection in the U.S.; foreign copyright protection may apply 2020 